Journal of Agricultural Sciences

Research Article

\title{
Reaction of Different Pepper (Capsicum annuum L.) Cultivars to Isolates of Verticillium dahliae Kleb. from Various Hosts
}

\author{
Furkan COŞKUN ${ }^{* 1}$, Yaşar ALPTEKİN ${ }^{2}$, Semra DEMİR ${ }^{3}$ \\ ${ }^{1,2}$ Kahramanmaras Sutcu Imam University, Agriculture Faculty, Plant Protection Department, Kahramanmaras, \\ Turkey \\ ${ }^{3}$ Van Yuzuncu Yil University, Agriculture Faculty, Plant Protection Department, Van, Turkey \\ ${ }^{1}$ https://orcid.org/0000-0003-2864-1515 ${ }^{2}$ https://orcid.org/0000-0002-4321-2834 ${ }^{3}$ https://orcid.org/0000-0002-0177-7677
}

*Corresponding author e-mail: furkan54777@gmail.com

\section{Article Info}

Received: 18.02 .2021

Accepted: 13.10 .2021

Online Published: 15.12.2021

DOI: 10.29133 /yyutbd.882449

\section{Keywords}

Pepper,

Disease Severity,

Cultivar,

Wilt,

Verticillium dahliae

\begin{abstract}
Although Verticillium dahliae is one of the limiting factors in pepper (Capsicum annuum L.) has no effective control measures, the most effective method is planting resistant cultivars. This study was carried out under controlled climatic conditions to determine the response of some economically important pepper cultivars grown in Turkey against some isolates of $V$. dahliae. Bafra $\mathrm{F}_{1}$, Ergenekon $F_{1}$ hybrid cultivars and Sena, Sera Demre 8, Doru 16 registered domestic pepper cultivars were used in this study. $V$. dahliae isolates (Bisak 16, Kahramanmaraş, Karpuz-2, Karpuz-4, Kayseri) obtained from different regions and hosts and diagnosed were used as a source of inoculums. The disease severity on inoculated plants in pots were calculated according to severity of the wilting ( $0-5$ scale) and browning of stem cut (0-3 scale). Significant differences were observed between pepper cultivars in terms of susceptibility to $V$. dahliae isolates. According to the study results, when the leaf symptoms were evaluated, varieties resistant to wilt disease were Ergenekon $F_{1}$ and Bafra $F_{1}$, while Sera Demre- 8 was determined as a susceptible variety. According to the browning symptoms of stem cut, while the resistant variety was Ergenekon $\mathrm{F}_{1}$, Sena was determined as the sensitive variety.
\end{abstract}

\section{Farklı Konukçulardan Elde Edilmiş Verticillium dahliae Kleb. İzolatlarına Karşı Bazı Biber (Capsicum annuum L.) Çeşitlerinin Reaksiyonlarının Belirlenmesi}

\section{Makale Bilgileri}

Geliş: 18.02 .2021

Kabul: 13.10 .2021

Online Yayınlanma: 15.12.2021

DOI: 10.29133 /yyutbd. 882449

\section{Anahtar Kelimeler}

Biber,

Hastalık Şiddeti,

Çeşit,

Solgunluk,

Verticillium dahliae
Öz: Biberde (Capsicum annuum L.) solgunluk hastalığı etmeni Verticillium dahliae'ya karşı başarılı bir mücadele yöntemi olmamakla birlikte en etkili yöntem olarak dayanıklı çeşit kullanımı önerilmektedir. Bu çalışma, ülkemizde yaygın olarak yetiştirilen bazı biber çeşitlerinin, $V$. dahliae'nın bazı izolatlarına karşı duyarlılıklarını belirlemek amacıyla iklim odası koşullarında yürütülmüştür. Araştırmada biber çeşidi olarak Bafra $F_{1}$, Ergenekon $F_{1}$ hibrit çeşitleri ve Sena, Sera Demre 8 ve Doru 16 tescilli yerel biber çeşitleri kullanılmıştır. Farklı bölge ve konukçulardan izole edilen ve tanılaması yapılmış $V$. dahliae fungus izolatları (Bisak 16, Kahramanmaraş, Karpuz-2, Karpuz-4, Kayseri) kullanılmıştır. Saksı denemelerinde yapay inokulasyon yapılmış bitkilerde ortaya çıkan hastalık şiddetleri, yeşil aksamda solgunluk şiddeti ve gövde kesitinde gözlenen kahverengileşmenin yoğunluğuna göre hesaplanmıştır. Solgunluk hastalığına duyarlılık açısından çeşitler arasındaki farkın, istatistiksel açıdan önemli $(\mathrm{P}<0.05)$ olduğu saptanmıştır. Çalışma sonucuna göre, yaprakta oluşturulan simptomlar değerlendirildiğinde solgunluk hastalığına dayanıklı çeşitler Ergenekon $F_{1}$ ve Bafra $\mathrm{F}_{1}$ olurken, Sera Demre-8 hassas çeşit olarak tespit edilmiştir. İletim demeti simptomlarına göre ise dayanıklı çeşidin Ergenekon $F_{1}$ olduğu belirlenirken, Sena hassas çeşit olarak tespit edilmiştir. 


\section{Introduction}

Pepper (Capsicum annuum L.), a member of the Solanaceae family, is widely cultivated and consumed worldwide (Csilléry, 2006). Pepper plants have grown widely in Turkey for several purposes and in different forms such as spices, fresh, bell pepper, capia pepper, isot (fermented and dried local peppers), pickled peppers, jalapeno peppers, pepper sauce, and paste (Özalp, 2010). Annually about 2.5 million tons (fresh fruit) of pepper is produced in Turkey and it has $6.9 \%$ of the world total pepper production in 2018 (FAO, 2020). Mediterranean Region meets about $40 \%$ of the total pepper production of Turkey. Especially in Eastern Mediterranean Region (Adana, Mersin, Hatay, Kahramanmaraş, and Osmaniye provinces), 532.057 tons of pepper is produced, such a production alone accounts for approximately $50.7 \%$ of the pepper production of the Mediterranean Region and approximately $20.2 \%$ of pepper production of Turkey (TÜIK, 2020).

Since pepper is an essential source of income for farmers, management of diseases and control of pests that cause serious economic losses in pepper is an important issue. Fungal diseases cause approximately about 14\% yield loss in vegetable production in the world (Agarwal and Sinclair, 1997; Agrios, 1997). Fungi such as Phytophthora capsici, Rhizoctonia spp., Fusarium spp., Pythium spp., Alternaria spp., Verticillium dahliae, Pyrenochaeta lycopersici, and Botrytis cinerea cause severe diseases in plants such as root blight, root rot, wilt and collapse, and fruit rot in pepper growing areas (Ecevit et al., 1988; Douira et al., 1995; Chellemi et al., 2000; Troncoso et al., 2005; Nguyen et al., 2010). Among these diseases, $V$. dahliae is one of the most destructive pathogen causing vascular wilt in pepper plants (Saydam and Copçu, 1973; Kırbağ and Turan, 2006; Kılıç, 2012; Taşkın and Y1k1lmazsoy, 2014). It influences pepper growth, fruit yield, and fruit quality.

$V$. dahliae has a broad host spectrum and can infect more than 200 plant species worldwide. To overcome adverse climatic conditions, it forms a resistant structure called microsclerotia $(10-120 \mu \mathrm{m})$ in soil. It can resist in soil for over ten years. Germination of microsclerotia is stimulated by root exudates released from susceptible hosts, and a mycelium is formed that infects the roots (Agrios, 1997, 2005; Koike et al., 2007; Koç, 2014; Korhan, 2019). The fungus invades both the intracellular and intercellular spaces and reaches the xylem, where it forms the conidia and mycelium and reaches the apex, leaves, and upper parts of the plant where it secretes enzymes with toxic effects, causing yellowing and drying of the leaves. The xylem and leaves lose their function partially or completely. $V$. dahliae causes wilting because the pathogen is heavily colonized in the xylem tissue, and the plant forms tylose to prevent pathogen movement, thus preventing the transport of nutrients due to clogging of the xylem. In the management of the disease; Cultural methods such as crop rotation, sanitation, balanced fertilization, irrigation management, weed control, and development of resistant cultivars are recommended (Balcı and Açıkgöz, 2019).

Management of Verticillium wilt is difficult due to the absence of any effective chemicals to suppress wilting diseases. The use of resistant cultivars is the most effective way to control this disease. Masheva and Todorova (2013) tested the performance of twenty different pepper genotypes by using two methods - direct planting in infected soil and infestation in transplanting by root-dip technique and planting in the same soil against $V$. dahliae. They found that tested genotypes performed better in infested soil than the root-dip method, and breeding line 398/03 was highly resistant to the two ways of infestation. They suggested that breeding line 398/03 could be used source of resistance in future breeding programs. Vasileva et al. (2019) found that Buketen 3, Buketen 50, Gorogled 6, IZK Rubin, and IZK Kalin cultivars showed a high resistance level with no diseases symptoms from mass flowering to fruit setting period after inoculation with a mixed inoculum of six local isolates of $V$. dahliae. Vasileva and Todorova (2020) reported that Kurtovska kapia 1, Milkana $F_{1}$, and Stryama cultivars were highly resistant to $V$. dahliae.

Nowadays, the need to seek alternative control measures (i.e., biological control agents, essential oils, resistant cultivars) that are environmentally friendly and with no hazards in humans has increased. To our best knowledge, there is not any detailed study on the screening of different pepper cultivars against $V$. dahliae both in the greenhouse and field in Turkey. Therefore, the current study aimed to determine (i) the pathogenicity of $V$. dahliae isolates isolated from different regions and hosts, (ii) the reactions of the different pepper cultivars to different isolates. 


\section{Materials and Methods}

\subsection{Plant material}

In this study, hybrid (Bafra $F_{1}$ and Ergenekon $F_{1}$ pepper) and local (Sena, Sera Demre-8, and Doru-16) pepper cultivars were used as plant materials. The susceptibility of the hybrid pepper cultivars used in the study to root diseases was determined in previous studies (Aslanpay and Demir, 2015; Demir et al., 2015). The local cultivars used in the study were those grown intensively in the Mediterranean Region.

\subsection{Pathogen isolate}

V. dahliae isolates (Bisak 16, Kahramanmaraş, Karpuz-2, Karpuz-4, and Kayseri), isolated from different regions and host plants and diagnosed were used as sources of inoculum. $V$. dahliae Bisak 16 isolate from eggplant is supplied by Prof. Dr. Şener KURT, (Hatay Mustafa Kemal University, Faculty of Agriculture, Department of Plant Protection, Hatay) $V$. dahliae Kahramanmaraş isolate, from cotton plant supplied by Doğan GÖZCÜ (Director of the Eastern Mediterranean Transitional Zone Agricultural Research Institute), $V$. dahliae Karpuz-2 and Karpuz-4 isolates, from watermelon plant supplied by Prof. Dr. Harun BAYRAKTAR (Ankara University, Faculty of Agriculture, Department of Plant Protection, Ankara) and $V$. dahliae Kayseri isolate, from eggplant plant supplied by Prof. Dr. H. Handan ALTINOK (Erciyes University, Faculty of Agriculture, Department of Plant Protection, Kayseri).

\subsection{Plant growing conditions}

Peat and perlite mixture (1:1 ratio) was placed into plastic cups of $0.35 \mathrm{~L}$, and vermiculite was used as a cover. Pepper seeds were washed three times with distilled water, kept in $2 \% \mathrm{NaOH}$ solution for 5 minutes, and then passed through double-distilled water to achieve surface disinfection. One seed was sown in each cup. The seedlings were cultivated in a climatic chamber with 12:12 hours light: dark period, at $22 \pm 2{ }^{\circ} \mathrm{C}$ temperature, and $60-70 \%$ relative humidity conditions; the seedling growth was monitored daily. The seedbeds were watered with a nutrient solution diluted to give $5 \mathrm{ml}$ for each cup three times during the growing period (Şavur, 2015).

\subsection{Pathogenicity tests}

$V$. dahliae isolates were grown in PDA (Potato Dextrose Agar) medium to determine their virulence on different pepper cultivars. Fungal cultures were transferred to PDA medium in petri dishes and allowed to grow at $24^{\circ} \mathrm{C}$ in a 12-hour dark-light cycle in purple light for ten days.

The study was conducted with a randomized block design with three replications. Pepper seedlings were inoculated with $V$. dahliae isolates and allowed to grow in a climatic chamber for six weeks. Before inoculation, fungal discs ( $5 \mathrm{~mm}$ in diameter) were taken from the $V$. dahliae isolates grown in $9 \mathrm{~cm}$ petri dishes using cork borer and transferred into the stock suspension solution (Solution A: $\mathrm{Ca}(\mathrm{NO}), \mathrm{KNO}_{3}$; Solution B: $\mathrm{K}_{2} \mathrm{SO}_{4}$; Solution C: $\mathrm{KH}_{2} \mathrm{PO}_{4}$; Solution D: $\mathrm{K}_{2} \mathrm{HPO}_{4}$; Solution E: $\mathrm{C}_{6} \mathrm{H}_{8} \mathrm{O}_{7}$, $\mathrm{C}_{4} \mathrm{H}_{6} \mathrm{O}_{5}$; Oligo-elements; $\mathrm{Fe}$ (Sequestrene 138), $\left.\mathrm{MnSO}_{4}, \mathrm{CuSO}_{4}, \mathrm{ZnSO}_{4}, \mathrm{Na}_{2}\left[\mathrm{~B}_{4} \mathrm{O}_{5}(\mathrm{OH})_{4}\right] \cdot 8 \mathrm{H}_{2} \mathrm{O}\right)$ (Kabaş, 2008). The spore suspension of the isolates to be used as an inoculum in pathogenicity tests was obtained as the $V$. dahliae colonies in petri dishes and was shaken using an orbital shaker at $50 \mathrm{rpm}$ for eight days. The concentration of spore suspension was adjusted to $1 \times 10^{6}$ conidia $/ \mathrm{ml}$ via a hemocytometer. The roots of pepper seedlings were inoculated by dipping into the spore suspension for 5 minutes. The control plant roots were dipped in sterile distilled water instead of the fungal conidial suspension (Yeşilova and Karaca, 2007).

The disease symptoms were evaluated at the end of a 10-week growing period, and the disease severity was determined. For this purpose, a $0-5$ scale $(0=$ Healthy; $1=$ Less than $25 \%$ wilt in leaves; $2=25 \%-50 \%$ wilt ( $30 \%$ leaf loss); $3=50 \%-75 \%$ wilt ( $60 \%$ leaf loss); $4=75 \%-100 \%$ wilt ( $90 \%$ leaf loss); $5=$ The plant is dead) was used for wilt assessment in plant canopy (Hwang et al., 1992) and a 0 3 scale $(0=$ The plants are healthy, no discoloration in the stem cross-section; $1=$ The plants are slightly diseased, small brown stains in the stem cross-section, $1-33 \%$ of the vascular bundles are browned; $2=$ 
The plants are moderately diseased, there are many black spots on the stem cross-section, $34-67 \%$ of the vascular bundles are browned; $3=$ The plants are heavily diseased, stem cross-sections are completely covered with black spots, and the plants are dried, $68-100 \%$ of the vascular bundles are browned) was used for the examination of the stem cross-section (Erwin et al., 1976). For both scales, the degree of disease severity was calculated using the following formula:

$$
\text { Disease Severity }=\sum \frac{(n * v)}{\mathrm{N} * \mathrm{~V}} * 100
$$

where; $\mathrm{n}=$ Degree of disease severity rated on a scale, $\mathrm{v}=$ Number of plants in a category, $\mathrm{N}=$ The highest degree of disease severity, and $\mathrm{V}=$ Total number of plants screened.

The seedlings were removed from the plastic cups at the root parts were washed under tap water to remove soil particles adhered to the roots. Koch postulates were performed to be sure that the isolates were infected and caused the disease on the seedlings (Yıldız and Benlioğlu, 2013).

\subsection{Data evaluation}

SPSS (Version 22.0) software was used to evaluate the data obtained from the experiments (Spss, 2013). Duncan's multiple comparison test was used to differentiate the means of the treatments. The data were analyzed by one-way ANOVA.

\section{Results}

In the present study, five different pepper cultivars (Bafra $F_{1}$, Ergenekon $F_{1}$, Sena, Sera Demre8, Doru-16) were inoculated with five different isolates (Bisak-16, Kahramanmaraş, Karpuz-2, Karpuz4 , Kayseri). The disease severity values obtained using 0-5 scale are provided in Table 1 . The symptoms started to appear in plants four weeks after pathogen inoculation. Yellowing and discolouration in lower leaves were observed, although the edges of the leaves roll inward were present in upper leaves. (Figure1).

Table 1. Reactions of different pepper cultivars to different $V$. dahliae isolates (0-5 Scale Green Part Evaluation)

\begin{tabular}{|c|c|c|c|c|c|c|}
\hline \multicolumn{7}{|c|}{ Disease Severity (\%) } \\
\hline \multicolumn{7}{|c|}{ Pathogen isolates } \\
\hline Cultivars & Bisak-16 & Karpuz-2 & Karpuz-4 & Kayseri & Kahramanmaraş & Avg. \\
\hline Doru-16 & $13.3 \pm 6.6^{\text {cde }}$ & $0 \pm 0^{\mathrm{e}}$ & $6.6 \pm 6.6^{\mathrm{de}}$ & $26.6 \pm 6.6^{\mathrm{bcd}}$ & $20 \pm 0^{\text {cde }}$ & 13.3 \\
\hline Sena & $26.6 \pm 6.6^{\mathrm{bcd}}$ & $26.6 \pm 6.6^{\mathrm{bcd}}$ & $20 \pm 0^{\text {cde }}$ & $6.6 \pm 6.6^{\mathrm{de}}$ & $33.3 \pm 6.6^{\mathrm{abc}}$ & 22.6 \\
\hline Sera Demre-8 & $35 \pm 9.57^{\mathrm{abc}}$ & $20 \pm 11.54^{\text {cde }}$ & $26.6 \pm 6.6^{\mathrm{bcd}}$ & $46.6 \pm 6.6^{\mathrm{ab}}$ & $53.3 \pm 6.6^{\mathrm{a}^{*}}$ & 36.3 \\
\hline Bafra $F_{1}$ & $15 \pm 5^{\text {cde }}$ & $6.6 \pm 6.6^{\mathrm{de}}$ & $26.6 \pm 6.6^{\mathrm{bcd}}$ & $26.6 \pm 6.6^{\mathrm{bcd}}$ & $6.6 \pm 6.6^{\mathrm{de}}$ & 16.2 \\
\hline Ergenekon $F_{1}$ & $10 \pm 5^{\mathrm{de}}$ & $13.3 \pm 6.6^{\text {cde }}$ & $20 \pm 0^{\text {cde }}$ & $13.3 \pm 6.6^{\text {cde }}$ & $6.6 \pm 6.6^{\mathrm{de}}$ & 12.6 \\
\hline Avg. & 19.98 & 13.3 & 19.96 & 23.94 & 23.96 & \\
\hline
\end{tabular}

*: Means followed by different letters were significantly different according to Duncan's multiple range test at $\mathrm{P}<0.05$ (Avg.: Average).

Virulence of $V$. dahliae isolates and the reactions of the pepper cultivars were significant according to 0-5 scale. Doru-16 pepper cultivar displayed the lowest disease severity values against Karpuz-2 (0\%) and Karpuz-4 (6.6\%) isolates, whereas it showed the highest disease severity values against Kayseri (26.6\%) and Kahramanmaraş (20\%) isolates. Sena pepper cultivar resulted in the least disease severity values against Kayseri (6.6\%) isolate, although it exhibited the highest disease severity values against Kahramanmaraş (33.3\%) isolate. Sera Demre-8 produced 20\% disease when inoculated with Karpuz-2 isolate and 53.3\% disease inoculated with Kahramanmaraş isolate. Bafra $F_{1}$ had the lowest disease severity against Karpuz-2 (6.6\%) and Kahramanmaraş (6.6\%) isolates but the highest disease severity against Karpuz-4 (26.6\%) and Kayseri (6.6\%) isolates (26.6\%). Ergenekon $\mathrm{F}_{1}$ had the least severe disease against the Kahramanmaraş (6.6\%) isolate, but the most severe disease was against Karpuz-4 (20\%). In summary, Sera Demre-8 was the most sensitive pepper cultivar with a disease 
severity of 36.3 percent on average, while Ergenekon $F_{1}$ was the most resistant with a disease severity of 12.6 percent on average. Kahramanmaraş, on the other hand, was the most virulent isolate (average disease severity $23.96 \%$ ), whereas Karpuz-2 was the least virulent (average disease severity $13.3 \%$ ).

As the interactions between $V$. dahliae isolates and pepper cultivars were evaluated, the highest disease severity was recorded in Sera Demre-8 x Kahramanmaraş interaction with 53\%, and the lowest disease severity (no disease) was recorded in Karpuz-2 x Doru-16 interaction.

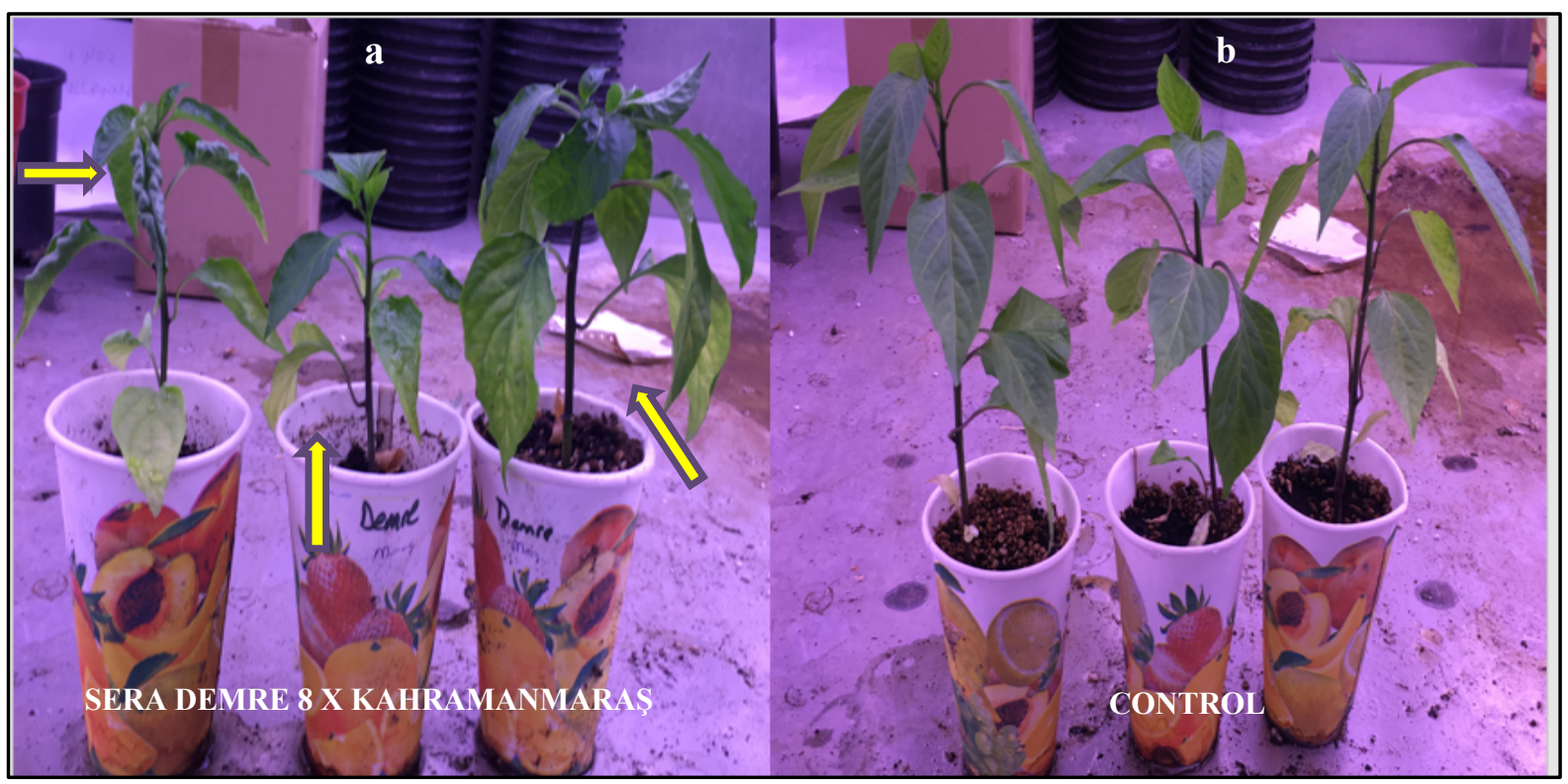

Figure 1. The view of diseased (a) and healthy (b) pepper plants inoculated with $V$. dahliae isolates after 4 weeks.

The disease severity values obtained by evaluating stem cross-sections ( $0-3$ scale $)$ of pepper cultivars inoculated by $V$. dahliae isolates are provided in Table 2 .

Table 2. Reactions of different pepper cultivars against different $V$. dahliae isolates (0-3 Scale Stem Section Evaluation)

\begin{tabular}{lllllll}
\hline \multicolumn{7}{c}{ Disease Severity (\%) } \\
\hline Pathogen isolates \\
\hline Cultivars & Bisak-16 & Karpuz-2 & Karpuz-4 & Kayseri & Kahramanmaraş & Avg. \\
\hline Doru-16 & $11.1 \pm 11.1^{\mathrm{bc}}$ & $22.2 \pm 22.2^{\mathrm{abc}}$ & $0 \pm 0^{\mathrm{c}}$ & $11.1 \pm 11.1^{\mathrm{bc}}$ & $44.4 \pm 22.2^{\mathrm{ab}}$ & 17.7 \\
Sena & $22.2 \pm 11.1^{\mathrm{abc}}$ & $33.3 \pm 0^{\mathrm{abc}}$ & $11.1 \pm 11.1^{\mathrm{bc}}$ & $11.1 \pm 11.1^{\mathrm{bc}}$ & $33.3 \pm 0^{\mathrm{abc}}$ & 22.2 \\
Sera Demre-8 & $33.3 \pm 0^{\mathrm{abc}}$ & $11.1 \pm 11.1^{\mathrm{bc}}$ & $0 \pm 0^{\mathrm{c}}$ & $0 \pm 0^{\mathrm{c}}$ & $55.5 \pm 22.2^{\mathrm{a}^{*}}$ & 19.9 \\
Bafra $\mathbf{F}_{\mathbf{1}}$ & $50 \pm 0^{\mathrm{ab}}$ & $0 \pm 0^{\mathrm{c}}$ & $0 \pm 0^{\mathrm{c}}$ & $11.1 \pm 11.1^{\mathrm{bc}}$ & $33.3 \pm 0^{\mathrm{abc}}$ & 18.8 \\
Ergenekon $\mathbf{F}_{\mathbf{1}}$ & $25 \pm 0^{\mathrm{abc}}$ & $0 \pm 0^{\mathrm{c}}$ & $22.2 \pm 11.1^{\mathrm{abc}}$ & $0 \pm 0^{\mathrm{c}}$ & $11.1 \pm 11.1^{\mathrm{bc}}$ & 11.6 \\
Avg. & 28.3 & 13.3 & 6.6 & 6.6 & 35.5 & \\
\hline
\end{tabular}

*: Means followed by different letters were significantly different according to Duncan's multiple range test at $\mathrm{P}<0.05$ (Avg.: Average).

Considering the disease severity caused by different $V$. dahliae isolates on different pepper cultivars (0-3 Scale Stem Section Evaluation), $V$. dahliae isolates' virulence and the interactions between the cultivars and isolates were found to be significant. However, most of these values were intertwined and were included in close groups. Doru-16 pepper cultivar displayed the lowest disease severity $(0 \%)$ against Karpuz-4 isolate, although it showed the highest disease severity (44.4\%) against Kahramanmaraş isolate. Sena pepper cultivar indicated the least severe disease against Kayseri $(11.1 \%)$ and Karpuz-4 (11.1\%) isolates, but the most severe diseases were against Kahramanmaraş (33.3\%) and Karpuz-2 (33.3\%) isolates. Sera Demre-8 pepper cultivar was highly resistant against Karpuz-4 (0\%) and Kayseri $(0 \%)$ isolates, whereas it was susceptible against Kahramanmaraş isolate (55.5\%). Bafra $\mathrm{F}_{1}$ was highly resistant against Karpuz-2 (0\%) and Karpuz-4 (0\%) isolates, although it was susceptible 
against Bisak-16 isolate $(50 \%)$. Ergenekon $\mathrm{F}_{1}$ produced no disease $(0 \%)$ when inoculated with Karpuz2 and Kayseri isolates; it showed 25\% disease severity values inoculated with Bisak-16 isolate. In concise, Sena was the most sensitive pepper cultivar with a disease severity of $22.2 \%$ on average, while Ergenekon $F_{1}$ was the most resistant with a disease severity of $11.66 \%$ on average. On the other hand, Kahramanmaras was the most virulent isolate (average disease severity $35.52 \%$ ), whereas Karpuz-2 and Kayseri were the least virulent (average disease severity 6.66\%).

Kahramanmaraş isolates had the highest virulence with a disease severity of $55.5 \%$, followed by the Bisak-16 isolate with $50 \%$ (Figure $2 \mathrm{a}$ ). In terms of the interactions between $V$. dahliae isolates and pepper cultivars, the highest disease severity (53\%) was recorded in Sera Demre- $8 \mathrm{x}$ Kahramanmaraş interaction, and no disease symptoms (0\%) was recorded in Doru-16 x Karpuz-4, Demre-8 x Karpuz-4, Demre-8 x Kayseri, Bafra $F_{1}$ x Karpuz -2, Bafra $F_{1}$ x Karpuz -4, Ergenekon $F_{1}$ x Karpuz -2, Ergenekon $F_{1} \times$ Kayseri interactions (Figure 2b).

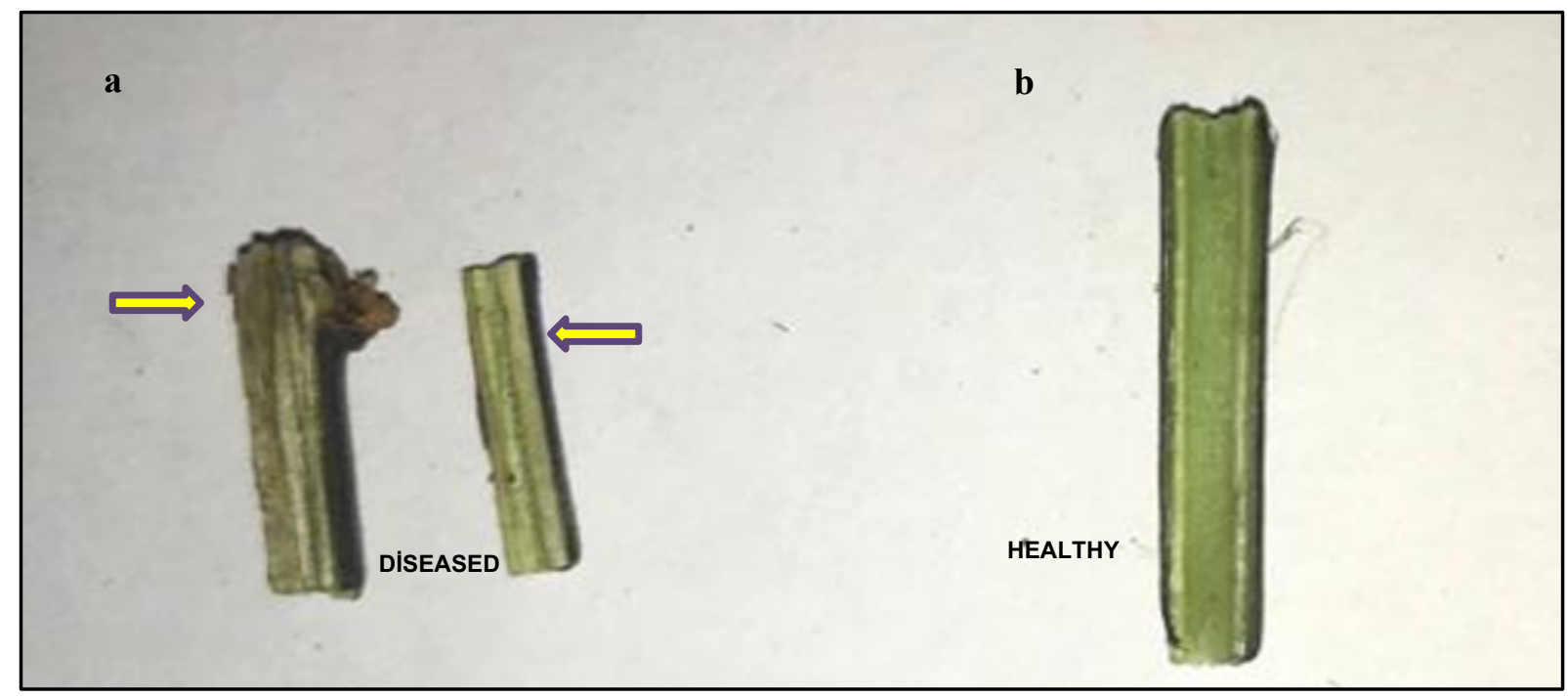

Figure 2. A view of stem cuts of pepper plants inoculated with $V$. dahliae; (a) diseased and (b) healthy plants.

Following pathogenicity and host reaction tests on the pepper plants, the disease agent was successfully isolated from each pepper plant that showed disease symptoms (Figure 3).

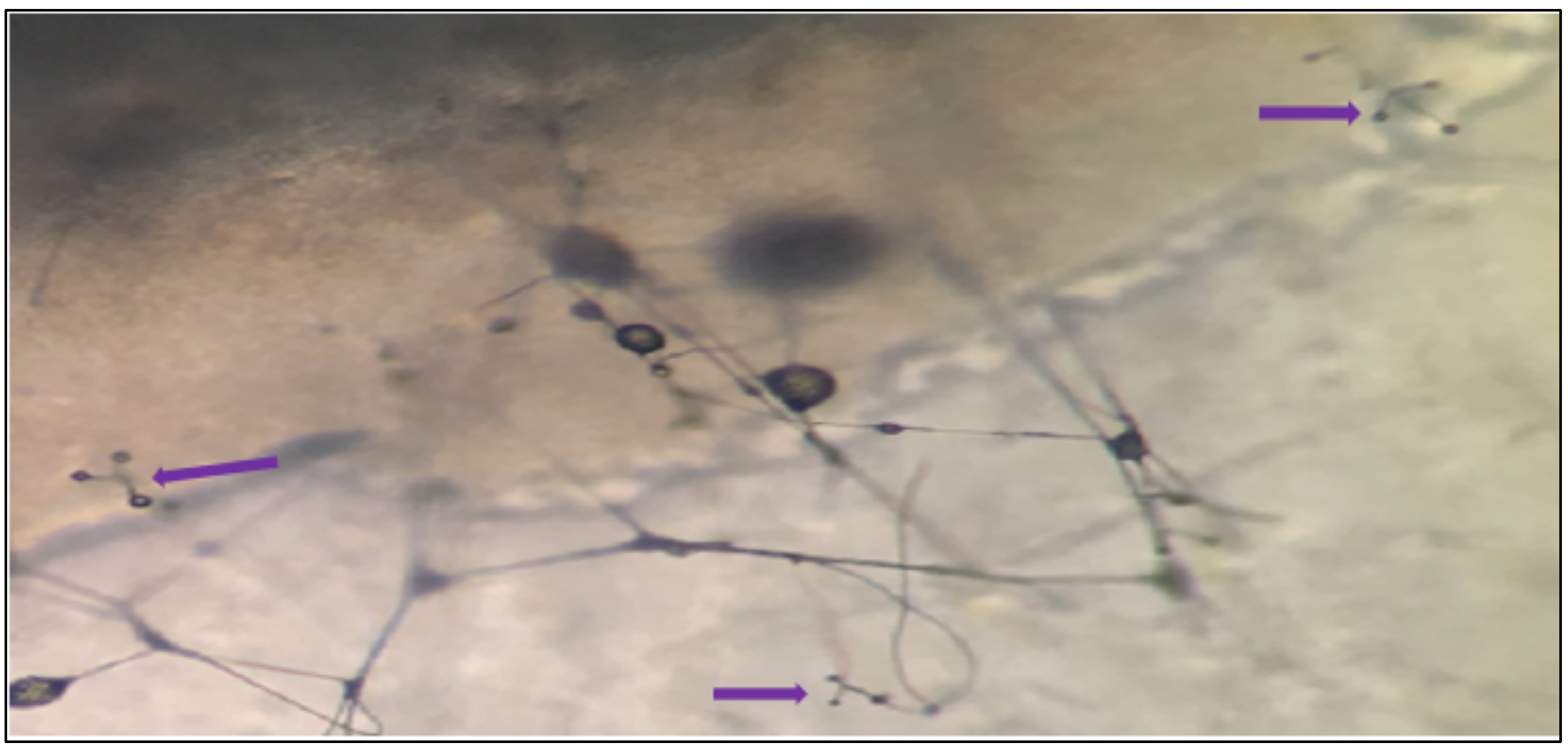

Figure 3. A view of re-isolated $V$. dahliae isolates with verticillate conidiophores under light microscope. 


\section{Discussion and Conclusion}

The virulence of five different $V$. dahliae isolates obtained and identified from different hosts and regions was first tested in detail against different pepper cultivars in vitro in our country. Doru-16 pepper cultivar displayed no disease symptoms followed by the inoculation with the Karpuz-2 isolate, although Sera Demre-8 inoculated with the Kahramanmaraş isolate showed the highest disease severity $(53 \%)(0-5$ scale). Many types of research have been conducted on the severity of diseases caused by $V$. dahliae, and it was stated that the severity of the disease was varied with the plant species. According to Akışcan and Tok (2019), there was a high correlation among the disease severity values of infected cotton plants with different genotypes evaluated via both 0-3 and 0-5 scales. Ecevit et al. (1988) identified Verticillium spp. as well as various fungi from vegetable fields. As a result of the pathogenicity tests, Verticillium spp. was found to be moderately virulent. Korkmaz (2005) conducted a study to determine the host vegetable species of Verticillium wilt disease and showed that pepper had the lowest mean among vegetable cultivars with a 0.14 disease severity index. In the study carried out by Bayözen (2007), the Çine pepper cultivar was inoculated with $V$. dahliae spore suspension using an insulin needle, and no signs of disease in the inoculated pepper plants were observed. Masheva and Todorova (2012) inoculated $V$. dahliae on nine different pepper cultivars in Bulgaria and calculated the wilt symptoms in plants using a 0-5 scale. Byal Kalinkov pepper cultivar showed the highest disease severity. Demir et al. (2015) inoculated tomato, pepper, eggplant plants with $V$. dahliae and calculated wilting symptoms with the use of a $0-5$ scale. Disease severity was identified as $45.19 \%$ in tomato, $44.44 \%$ in pepper, and 40.74\% in eggplant. Tutar and Erkılıç (2016) inoculated Pala eggplant cultivar with $V$. dahliae and calculated wilt symptoms with the use of a $0-5$ scale. The disease severity values varied between 47.5 $51.4 \%$. Sera Demre-8 was the most susceptible pepper cultivar when inoculated with the Kahramanmaraş isolate (55\%) (0-3 scale). It was shown that the Kahramanmaraş isolate was the most virulent, although the other isolates displayed similar reactions on pepper cultivars tested. Parallel to our results, the other researchers also reported that the host species from which the pathogen was isolated was significant due to the virulence of $V$. dahliae on different pepper cultivars. Demir et al. (2015) inoculated tomato, pepper, eggplant plants with $V$. dahliae and calculated stem section symptoms using a $0-3$ scale. The disease severity was identified as $55 \%$ in tomato, $56 \%$ in pepper, and $52 \%$ in eggplant. These studies reported similar results to the current study. It was demonstrated that the source of fungal isolate and genetic background of a pepper cultivar played an essential role in disease severity calculated by 0-3 and 0-5 scale. Erdoğan et al. (2011) calculated disease severity in the stem sections of cotton genotypes in naturally infested fields with Verticillium wilt using a 0-3 scale. As a result of the study, the tolerant Carmen cultivar showed the lowest disease severity value with an index value of 0.71 , followed by the cotton genotype number $1011(0.74)$. The highest disease severity value was found in the susceptible Çukurova 1518 cultivar (2.09).

Several types of research have been conducted on the virulence of different $V$. dahliae isolates against pepper cultivars and breeding lines with different genetic backgrounds in different countries. The disease severity was evaluated on twenty different pepper genotypes inoculated with $V$. dahliae using direct planting in naturally infested soil and root-dip inoculation techniques. The tested pepper cultivars showed a lower disease severity in naturally infested soil than in root dip inoculation. The lowest disease severity was observed on breeding line 398/03 when the pepper plants inoculated with both inoculation methods (Masheva and Todorova, 2013). In another study, Buketen 3, Buketen 50, Gorogled 6, IZK Rubin, and IZK Kalin pepper cultivars displayed no diseases symptoms from mass flowering to fruit setting period when they were inoculated with a mixed inoculum of six local isolates of $V$. dahliae in Bulgaria (Vasileva et al., 2019). Vasileva and Todorova (2020) reported that the Kaloyan cultivar was not infected by $V$. dahliae in a naturally infested field, although Kurtovska kapia 1, Zlaten medal 7, Milkana $F_{1}$ pepper cultivars showed the lowest disease severity with slight symptoms in the greenhouse.

In a not shell, as a result of this study conducted to determine the reaction of different pepper cultivars to isolates of $V$. dahliae from various hosts, it was detected that Ergenekon $\mathrm{F}_{1}$ was the most resistant cultivar according to the leaf symptoms and browning of stem cross-section. The encouraging results obtained in this study in the management of wilt caused by $V$. dahliae will shed light on new researchers to be conducted on this issue and contribute to the present literature. 


\section{Acknowledgement}

This project was supported by funds from the Scientific and Technological Research Council of Turkey (TÜBİTAK Project No. 119O059).

\section{References}

Agarwal, V. K., \& Sinclair, J. B. (1997). Principles of Seed Pathology (2nd ed.). FL: CRC, Press, p.539. Agrios, G. N. (1997). Plant Pathology. 4th Edition, Academic Press, San Diego, 200-216.

Akışcan, Y., \& Tok, F. M. (2019). Farklı kökenli bazı pamuk genotiplerinde Verticillium solgunluğuna dayanıklılığın araştırılması. Kahramanmaraş Sütçü İmam Üniversitesi Tarım ve Doğa Dergisi 22, 354-360. doi:10.18016/ksutarimdoga.vi.544323

Aslanpay, B., \& Demir, S. (2015). Arbusküler mikorhizal fungus (AMF) ve hümik asitin biber (Capsicum annuum L.) bitkisinin gelişimi ve Phytophthora capsici Leonian'ın neden olduğu kök boğazı çürüklüğü hastalığına etkileri. Yüzüncü Yll Üniversitesi Tarım Bilimleri Dergisi 25 (1), 48-57. doi:10.29133/yyutbd.236390

Balc1, D. K. \& Açıkgöz, S. (2019). Pamuk solgunluk hastalık etmeni Verticillium dahliae Kleb.'da Mikovirüs dsRNA analizi ve RT-PCR İle tanılanması. Yüzüncü Yıl Üniversitesi Tarım Bilimleri Dergisi 29 (3), 516-525. doi: 10.29133/yyutbd.496476

Bayözen A. (2007). Mikorizal fungusların çilek ve biber bitkilerinin gelişimine ve sorun olan bazı patojenlerin gelişimine etkisinin saptanması (Yüksek Lisans Tezi). Adnan Menderes Üniversitesi Fen Bilimleri Enstitüsü Bitki Koruma Ana Bilim Dalı, Aydın.

Chellemi, D. O., Mitchell, D. J., Kannwischer-Mitchell, M. E., Rayside, P. A., \& Rosskopf, E. N. (2000). Pythium spp. associated with bell pepper production in Florida. Plant Disease 84, 1271-1274. doi:10.1094/PDIS.2000.84.12.1271

Csilléry, G. (2006). Pepper taxonomy and the botanical description of the species. Acta Agronomica Hungarica 54 (2), 151-166. doi:10.1556/AAgr.54.2006.2.5

Demir, S., Şensoy, S., Ocak, E., Tüfenkçi, Ş., Demirer Durak, E., Erdinç, Ç., \& Ünsal H. (2015). Effects of arbuscular mycorrhizal fungus (AMF), humic acid and whey on wilt disease caused by Verticillium dahliae Kleb. in three solanaceous crops. Turkish Journal of Agriculture and Forestry 39 (2), 300-309. doi:10.3906/tar-1403-39

Douira, A., Ben Kirane, R., Ouazzzni Touhami, A., Okeke, B., \& Elhaloui, N. E. (1995). Verticillium wilt of pepper (Capsicum annuum) in Maroko. Journal of Phytopathology 143, 467-470.

Ecevit, O., Dündar, F., \& Turan, A. (1988). Bafra Ovasındaki önemli bitki hastalıkları ve sulamanın yaygınlaştırılması ile ortaya çıkabilecek sorunlar ve çözüm yolları. Ondokuz Mayıs Üniversitesi Yayinlart 40, 1-351.

Erdoğan, O., Dündar H., \& Göre, M. E. (2011). Determination of reactions of some cotton genotypes against Verticillium wilt disease caused by Verticillium dahliae Kleb. Plant Protection Bulletin 51 (2), 159-173.

Erwin, D. C., Tsoti, S. D., \& Khan, R. A. (1976). Reduction of severity of Verticillium wilt of cotton by the growth retardants Tributyl (5-chloro-2-thienyl methyl) Phosphonium Chloride. Phytopathology 66, 106-110.

FAO (Food and Agriculture Organization of the United Nations), (2020). World pepper production. http://www.fao.org/faostat/en/\#data/QC. Last Accessed Date: 21 August 2020.

Hwang, S. F., Chang, K. F., \& Chakravarty, P. (1992). Effect of vesicular-arbuscular mycorrhizal fungi on the development of Verticillium and Fusarium wilts of alfalfa. Plant Disease 76, 239-243.

Kabaş, A. (2008). Domateste Fusarium oxysporum f.sp. radicis-lycopersici'ye karşı dayanıklılık için moleküler işaretleyicilerin belirlenmesi (Doktora Tezi). Ege Üniversitesi Fen Bilimleri Enstitüsü Bahçe Bitkileri Anabilim Dalı, İzmir.

Kılıç, G. (2012). Samsun ili kapya biber yetiştirilen alanlarda bulunan fungal etmenlerin tespiti ve patojeniteleri (Yüksek Lisans Tezi). Ondokuz Mayıs Üniversitesi Fen Bilimleri Enstitüsü Bitki Koruma Anabilim Dal1, Samsun.

Kirbağ, S., \& Turan, N. (2006). Fungal agents that cause root and crown rot of some vegetables cultivated in Malatya. Firat University Journal of Engineering Science 18 (2), 159-164. 
Koç, Ü. T. (2014). Antalya ili örtüaltı alanlarında aşıll fidelerden yetiştirilen patlıcanlarda görülen Verticillium dahliae Kleb. izolatlarının moleküler yöntemler kullanarak tespit ve tanımlanması (Yüksek Lisans Tezi). Akdeniz Üniversitesi Fen Bilimleri Enstitüsü Bitki Koruma Ana Bilim Dalı, Antalya.

Koike, S. T., Gladders, P., \& Paulus, A. O. (2007). Vegetable Diseases, A Colour Handbook, 1-449.

Korhan, H. (2019). Bazi antagonistik bakterilerin pamukta (Gossypium hirsutum L.) bitki gelişimine ve Verticillium solgunluğuna (Verticillium dahliae Kleb.) etkisi (Doktora Tezi). Kahramanmaraş Sütçü İmam Üniversitesi Fen Bilimleri Enstitüsü Tarla Bitkileri Ana Bilim Dalı, Kahramanmaraş.

Korkmaz, H. Y. (2005). Pamuk solgunluk hastalı̆g etmeni Verticillium dahliae Kleb. izolatlarının morfolojik ve patolojik özellikleri ve bazı pamuk çeşitlerinin hastalı̆ga tepkisi (Yüksek Lisans Tezi). Kahramanmaraş Sütçü İmam Üniversitesi Fen Bilimleri Enstitüsü Bitki Koruma Anabilim Dalı, Kahramanmaraş.

Masheva, S., \& Todorova V. (2012). Response of bulgarian pepper cultivars to causal agent of Verticillium wilt (Verticillium dahliae Kleb.). Plant Science 49, 23-28.

Masheva, S., \& Todorova V. (2013). Response of pepper varieties, $F_{1}$ hybrids and breeding lines to Verticillium dahliae Kleb. in two methods of infestation. Bulgarian Journal of Agricultural Science 19, 133-138.

Nguyen, V. T., Edward C. Y. L., \& Lester W. B. (2010). Characterization of P. capsici isolates from black pepper in Vietnam. Fungal Biology 114, 160-170. doi.org:10.1016/j.funbio.2009.11.005

Özalp, R. (2010). Ülkemizde biber üretimi ve örtüaltı biber yetiştiriciliği. Tarım Türk Dergisi 24 (5), 29-32.

Saydam, C., \& Copçu M. (1973). Verticillium wilt in Ege Region and its importance on some vegetables. J. Turkish Phytopathology 2 (1), 34-40.

Spss, I. (2013). IBM SPSS Statistics for Windows, Version 22.0. Armonk, NY: IBM Corp.

Şavur, O. B. (2015). Domates kök ve kök boğazı çürüklüğü hastalı̆̆ına (Fusarium oxysporum f.sp. radicis- lycopersici Jarvis \& Shoemaker) karşı arbusküler mikorhiza (AMF) ve salisilik asit uygulamalarının domates (Lycopersicum esculantum L.) bitkisinin bazı gelişim ve verim parametreleri ile hastalık şiddetine etkisi (Doktora Tezi). Yüzüncü Y1l Üniversitesi Fen Bilimleri Enstitüsü Bitki Koruma Anabilim Dalı, Van.

Taşkın, T., \& Yıkılmazsoy, G. (2014). Fungal diseases detected in some vegetables grown in Aegean Region. Turkey 5. Plant Protection Congress, 3-5 February, Antalya, p. 252.

Troncoso, R., Espinoza, C., Sánchez-Estrada, A., Tiznado, M. E., \& García, S. H. (2005). Analysis of the İsothiocyanates Present in cabbage leaves extract and their potential application to control Alternaria rot in bell peppers. Food Research International 38, 701-708. doi.org:10.1016/j.foodres.2005.02.004

Tutar, F. K., \& Erkılıç, A. (2016). Determination of the effects of mycorrhizal fungi and abiotic inducers against eggplant wilt diseases (Verticillium dahliae and Fusarium oxysporum f.sp. melongenae). Çukurova University Journal of Science and Engineering 34 (5), 32-42.

TÜIK (Turkish Statistical Institute), (2020). Crop production statistics. https://biruni.tuik.gov.tr/medas/?kn=92\&locale=tr. Last Accessed Date: 21 August 2020.

Vasileva, K., Todorova, V., \& Masheva, S. (2019). Evaluation of collection of pepper (Capsicum spp.) resources for resistance to Verticillium dahliae Kleb. Bulgarian Journal of Agricultural Science 25 (5), 1030-1038.

Vasileva, K., \& Todorova V. (2020). Evaluation of pepper (Capsicum annuum L.) varieties to several methods of inoculation with Verticillium dahliae Kleb. in different conditions. Bulgarian Journal of Agricultural Science 26 (2), 423-430.

Yeşilova, O., \& Karaca G. (2007). Determination of the effects of arbuscular mycorrhizal fungi on plant growth and Fusarium wilt of melon plants. Acta Horticulturae 729, 493-498.

Yıldız, A., \& Benlioğlu S. (2013). A laboratory bioassay for evaluating pathogenicity of Macrophomina phaseolina and Rhizoctonia solani isolates to strawberry stolons. Phytoparasitica 41 (5), 367369. doi.org:10.1007/s12600-013-0370-5 